公募シンポジゥム $\mathrm{V}$

\section{肛門癌 \\ 司会 吉 雄 敏 文
特別発言 鬼 束 惇 哉}

発言(司会) 吉 雄 敏 文

では “肛門癌”のシンポジウムを始めます。シンポジ ウムの題名は“肛門癌”となって扣りますが，抄録内容 を拝見しますと，肚門部だけでなく，肛門部周辺の洒性 腫瘍について触れておられる方がありますので，そうい う広、意味での内容になるかと思います。

\section{（1）肛門部恵性腫瘍症例の検討}

東大第 1 外科

○原 宏介, 土屋周二, 富山次郎 堀江良秋, 小林順弘

肛門部の悪性腫瘍は, 肛門管およびその周辺の解剖学 的構成の複雑さと相まって, 種々のものが発生すること が知られ，その名称に㧍ける混乱のもととなっている。

われわれは最近 9 年間に東大第 1 外科で診療した肛門 部の悪性腫瘍 8 例について, その病理, 㟝断, 治療法お よび成績を中心に検討を加えた。

この 8 例中扁平上皮癌, 細網肉腫各 1 例を除いた 6 例 は腺癌で，下部直腸癌が肛門部一発育したものと鑑別上 問題になるので，この点をとくに考虑して検索した，そ の結果, 直腸下端に生じた腺癌が肛門部一発育したと推 定されるものは 1 例で, 痔瘦を伴なった腺癌が 3 例, anal duct から生したと推定される腺癌が 2 例であっ た. 寸なわち肛門部悪性腫瘍 8 例中, anal canal および anal margin から生じたいわゆる肚門癌と推定されたの は扁平上皮癌 1 例, 腺癌 5 例, 計 6 例で, この期間の直 晹癌 112 例の $5.4 \%$ に相当する. 以下主な症例について報 告する.

症例 1 は扁平上皮癌の症例で, 病变は肚門管の扁平上 皮から生じ，歯状線をこえ上部肛門管をで及んだものと 推測される. 症例 2 は肛門輪から $8 \mathrm{~cm}$ 口側まで全楇に 及ぶ潰富を伴う腺澏で, 肉眼的および組織学的に一般に みられ直腸澏と全く同様の所見を示した. したがってこ の例は直腸癌が肛門外一発育したと推測した。症例 3 は 若、頃から痔核の既往があり，内侍核の手術の際に偶然
将核以外の特有な外観を有する小さな腫瘤が発見され た. 腫瘤は大きさ約 $1 \times 0.5 \mathrm{~cm}$ ，表面平滑な polypoid lesion で，位置は dentate line と anal margin の間に 存在し，組織学的には adenocarcinoma tubulare であ った，その表面は大部分が扁平上皮で被水ており，一 部で直腸粘膜と接していたところもあったが，腺癌が anal duct から扁平上皮の下へもぐり込んだかの上うな 位圈関係を示し, 病変の局在位直と組織像から anal duct から生じた腺涭ではないかと推測した。症例 4 は 5 年前から肛围㖶瘍または将瘦として数回手術を受けた が, 手術創が難治で, biopsy をうけ腺癌と診断された. 病変は anal margin に潰瘍を伴う腺癌であったが，直 腸および肛門管の粘膜には異常はみとめられなかった。 組織学的には adenocarcinoma muconodulare で, 腺 管を構成している上皮細胞法通常にみられる直腸癌より 丈の低い，cuboidal な細胞で占められているのが特徴的 であった。このように直腸粘膜とは無関係でしかも特有 の組織像を示すことから，この例も anal duct から生 じた腺癌ではないかと推測した. 次海症例 5，6，7の 3 例はそれぞれ $10 ， 30 ， 40$ 年も前から痔瘦が存在した症 例で，これらの組織像はいずれも adenocaacinoma tubulare または papillotubulare で每った。症例 8 は肛 門周囲の小指頭大のしこりが 6 カ月閒で急速に增大し， anal margin 加ら右犚部を占める巨大な腫瘤を形成した 例である. biopsy で lympho-reticulum cell sarcoma であった。

以上の 8 例の肚門部の悪性腫湟ををとめると，男子 6 例, 女子 2 例で年齢は 41 歳から 80 歳までで, 60 歳以上が 多いが，40歳代も2例みられた。主な症状は出血，疼 痛, 腫瘤, 硬結などで, 病悩期間は 6 カ月から 5 年に及

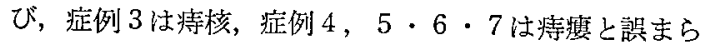
れて治療開始が遅れたものと考えられた，次江各症例の 病変とリンパ節転移, 治療法, 予後との関係をみると, 鼠径リンパ節転移は全例にみられた。治㙩法法扁平上皮 癌, 腺癌を問わず, 腹会陰式直腸切断術と鼠径りンパ節 郭清を基本方針としているが, 症例 5 は周囲臟器への浸 
潤のため放射線照射，症例 6 は病変は比較的限局してい たが，高龄なことと患者の拒否により，局所切除を抽こ なったところ 5 カ月後鼠径りンパ節転移，8力月後肺お よび皮膚転移を起し，間もなく死亡した，症例 7 は肛門 部および骨盤部への浸潤が大きいため，姑息的に内腸骨 動脈より $5 \mathrm{FU}$ を $250 \mathrm{mg}$ ，22日間持続注入したところ， 数日のうちに腫瘍は壊死に㧍ち入り脱落した．続いて放 射線照射をおこなったが，1年 8 カ後局所再発と肺転 移を起し現在入院中である.症例 8 の細網肉腫は病変が 進行しているため放射線照射をおこなったが経過が早く 6 力月後に死亡した. これに対し腹会陰式直腸切断術お よび鼠径リンバ節郭清をおこなった 4 例のうち 2 例は順 調で，そのうち症例 1 は扁平上皮癌で, 病変注比較的進 行していたが，術後放射線照射をおこない，2年 5 力月 後の現在健康である. 症例 3 は anal duct の腺癌と考 えられる症例で, 術後 2 年 3 力月後の現在健康である.

結論：(1)肛門部の悪性腫煌 8 例を検索し, 細網肉腫, 直腸癌の肛門部発育と推定されるもの各 1 例を除き，肛 門癌と考えられるものは 6例であった。(2)肛門癌6 例の らち，1例牥扁平上皮癌，2 例忙 anal duct 加ら生じ た腺癌と推定され，3 例法何らかの将遦と関係を疑わせ る腺癌であった（3)肛門部の悪性腫佰 8 例中 4 例が腹会 陰式直腸切断街扝よび鼠径リンパ節郭清をうりたが，扁 平上皮癌 1 例, 腺癌 1 例のみ，術後 2 年以上順調である が，放射線照射，局所切除，抗癌剤局所潅流をうけた 4 例はいずれも再発または死亡した，(4)肛門部の悪性腫焟 は痔核，痔瘦，肚門周囲の皮膚疾患などと誤まられるた め，症状があっても診断が遅れ，予後不良である。 した がって肚門部の難洽性疾患または見なれない病変がある 場合性 biopsy を行なう必要があると考えられる。

\section{（2）肛門部およびその周辺部癌}

\section{社会保険中央総合病院 \\ ○高野正博，岡田光生，平塚 品 任藤昭二，隅越幸男}

肛門部に見られる癌は多様性に富んでおり未だ普遍的 な分類は完成されていない，今回は直腸上り肛門に搪が った adenoca. を除外し, epidermoid ca. を中心し た14例について，肛門の外側から発生したと思われる症 例から先に紹介していくことにする。

症例 1 43歳合 肞囲に及ぶ潰瘍あり，主病変は肛門 を中心としている．組織住化，成熟した表皮癌であ る。転移は諗めら机ず，abdominoperineal resectionを 行ない 4 年問生存している。

症例 298 歳令 30 年来の将瘦からの出血, 疼痛があ
り，これは特瘦の悪化の徴候であるが，組織は㑇化成熟 渚るしい表皮癌であり，周囲への浸潤傾向強く，Miles を行なうもそけいリンパ節転移を起こし死亡している。 痔瘦から発生したと思われる例は後述の colloid ca. を 除けば本症例のみである。

症例 361 歳早 潰痬は肚門周辺に及び，尖圭コンヂ ロームを合併している．組織は浸潤傾向の強い basaloid cell nest を形成するが，一部では多少の角化も認めら れ，portio の癌に類似する. Miles の手術に続きCo 照射を行ならも 1 年後に死亡した．組織学的に肚門腺近 くの肛門上皮より発生したと考えられる症例である。 以 上，角化を伴な与成熟型の表皮癌でも浸潤傾向強く，予 後も悪いことが分る。

症例4 64歳合 肚門から周辺にわたり筋層に及ぶ病 変あり，組織は脸回様に浸潤する basaloid ca，である が，表皮内を in situ 様昖がる部分を見ると，多少の角 化傾向にある，局所切除汇続き Miles を行ない，10年 間生存している

症例 5 72歳古 肛門を中心とした限局性の crator 形成㐫り，組織で角化全くない basaloid cell nest が舌 様に浸潤しており，膀胱の移行上皮癌に類似し，いわゆ る transitional cell ca. (small cell type) と称せられ るむのであろう。すなわち直腸粘膜と肛門上皮の間のい わゆる cloacogenic zone上り発生したものであろう。

症例 6 は basal cell ca. の症例であるが，黑色を呈し ていたため malignant melanoma と誤まられたもの で，討論の際技見せしたい．

症例 7 62歳早 肛門部に crator 形成し, 組織で adeno ca. の部分と epidermoid ca. の部分とがあり， 下腸閒膜動脈に沿うリンパ節転移は mucin 産生強、軻 椂腺癌である. Miles を行なうも局所再発し，その組織 は未分化度の高、腺癌である，術後 3.カ月で死亡した。 転移部あるいは再発部で組織像が変化していることは， 肛門移行上皮由来の癌であることを示唆して招り興味が ある。

症例 8 66歳今 肛門直上に中心を有する。組織は mucin 産生の強い腺癌であるが表皮癌に似た nest を形 成し, Magen での adenoca. epid. mucocell. 江相当 する. Miles を行なうもそけい部に転移を来たした，予 後は不明である。

症例 943 歳令 直腸上部に位置する癌に対し anterior resection を行なったところ，組織はりっぱな表皮 癌で, Magen の ca. epid. kerat. に相当し, 大腸で は極めてまれとされている。. etiology としてはいるい ろ推測されているが，粘膜面の扁平上皮化が先行するこ とも考えられる. 5 カ月後に死亡した. 
症例10 41歳令 肛門部に発生した adeno ca. であ るが表皮下に密に浸潤し，一部で梳皮と連結してい る.

以下 4 例は肚門, 直腸周囲の colloid ca. である. 症例11 53歳含 35年前より㾌瘦あり, anal crypt と連続した腫瘤形成し,組織性 colloid 産生の強い adenoca，が筇層内に浸潤し，一層の上皮が剥離して自か ら産生した mucin 内に浮遊していく. pseudomyxoma peritonei に類似する.中仙骨動脈りンパ節転移あり， Miles 後 Co 照射を行ない， 2 年間生存している。組 織学的に肛門腺よりの発生が明らかで，討諭の時間に説 明を加えたい．

症例12も肚囲に瘦孔を作り, 症例13は直腸に瘦孔を作 り，症例14も同にく肛囲にゼラチンを分泌している。 こ れらの症例は特異な ca で移行上皮下の aberrent gland よりの発生も考えられる，われわれの例でのはいずれも 予後が良いのが特徵である。

以上の症例をまとめると，肛門部に発生する癌は，発 生部位, 病理組織学的に多岐にわたっており，2 者の組 合せによって非常に多種なものとなる。これらの症例の ほとんどに Miles 法を施行したが，、ずれも進行癌で， 予後は不良のものが多く; 成熟, 角化型の表皮癌の予後 も決して良くない，ただし，肛門值腸周囲に発生する colloid ca.では良好な成績を得た。

\section{（3）肛門部癌について}

東邦大学第 1 外科

○粕川 剛義, 亀谷寿彦, 吉雄敏文 西谷亮一郎，加藤 延，上田哲郎 淵之上弘道

われわれは1952年より1972年 7月までに，260例の直 腸肛門部の癌症例をとりあつかいました，今回は特に， 肚門管及びその周辺部の癌腫の実態を明らかにするた め，直腸肛門癌を 4 群に分けて比較検討致しました。す なわち, 第 1 群は癌腫の主要部分が, 肛門管に存在し, これはまた，臨床的には肚門癌 と診断されるものであ り，これに癌腫の一部分が dentate line に接している ものを加えました，第 2 群は癌腫が dentate line をは ずれて，肛門縁より $5 \mathrm{~cm}$ 以下に存在するもので，低位 直腸癌ともいうべき症例であります。

第 3 群は癌腫が肛門縁より $5.1 \mathrm{~cm}$ 以上, $10 \mathrm{~cm}$ 以下に 存在するものであります．第 4 群は癌腫が $10.1 \mathrm{~cm}$ 以上 に存在する症例であります，まず，各群について病悩期 をみますと, 直腸肛門部の癌腫の, 部位による有意の差 は認められませえでした。すなわち，これは肛門部の癌
腫は通常自覚症状が早期に出現するにもかかわらず，患 者自身が将疾患などと思い込み，受診時期が非常に遅れ ているためであります，また，肛門部癌で特筆される心゙ き特徵は，痔核，将癄，脱肛等の肛門部良性疾患の合併 が多く14例，約50\%であり，第 2 群では 6 例 $6.7 \%$ で著 明に減少しております。

これに伴ない肚門部慢性炎症疾患部より発生したと考 えられる癌腫の報告も散見し，われわれは本学会第22回 に，痔瘦を伴った肛門癌 4 例を報告致しましたが，これ は臨床病理学的に凑瘦より発生したと考えられる症例で あります，その後, 直腸および肛門癌に痔瘦を伴なうむ の7例をかぞえております。しかし，ここで注意すべき ことは, 肛門部癌が肛門周围膿瘍または痔瘦として発症 するものであります．かかる症例は癌と診断がっくまで に長期を要し，したがって予後は不良であります。

われわれは将瘦から一次性に起こった癌腫の決定を, Rasser の基準に従っております。すなわち癌が将瘦の 前に存在したという可能性を除くだけの十分長い期間, 痔霋が存在していること, 原発性の癌が直腸, 肛門の他 部位に存在していないこと，瘦管開口部が肛門管または crypt にあることであります.

われわれは第14回日本消化器病学会で発表した大腸癌 の病期分類に従い, この4 群を比較検討致しました. この分類は UICC および TNM 分類国内委員会の 規約にもとづいて，っくったものであり，第4 次リンパ 節転移, 肝転移などは遠隔転移 M の項に入れ，深達度 $\mathrm{P}$ およびリンパ節Nは組織診断により記載致します。こ の Stage I をわれわれは大腸早期癌と規定しておりま す、また Stage IIは胃癌取り扱い規約による絶対治瘉 切除可能な症例であり, Stage IIIは相対治瘾切除可能な 症例であり, Stage IVは非治癒切除が行なわれる症例で あります，このスライドで分るように癌腫が低位になれ ばなるほど，絶対治愈切除可能な Stage I およびIIが 増加し, 逆第 1 群においては, 非治癒切除例すなっち Stage IV が多い，これは肚門部癌の特性を良くあらわ していると考えられます。すなわち，数多い肛門部良性 疾患に混在している癌腫を，いささかの注意で早期に発 見しているといらこと，他方良性疾患として長い間めや まった治療が行な⿰れ，いたずらに癌腫の進行を許して いるということの 2 点であります。癌腫の組織像をみ ますと, 扁平上皮癌は 8 例であり，これは第 1 群および 第 2 群にまで存在して㧍ります。その他は単純癌㧍よび 腺滋で゙ありす。

肛門管㧍よびその周辺部癌における腺癌の特徵は粘液 変性を伴ならものが多く, 特に, muconodulare type が 大多数であります，腫㾤の発育形成をみますと，肍門部 
癌は肛門脱出傾向を有し，低位直腸癌では，肛門側に dentate line をこえて浸潤発育する、いわ化る junction type むみられます。

遠隔転移を各群について検討致しますと,ソケイリン パ節転移は第 1 群にのみみられ，他に転移例はありませ んでした．また，肝転移例は 1 群および 2 群では少な く, 癌腫が中位より上位に存在するものに多くみられ， 肺転移は第 1 および第 2 群にのみみられました。

これでわかる通り，肚門部癌のソケイリンパ節転移 は, 13.3\%に及び手術に際しては,このリンパ節廓清を無 視すること法できません，1968年教室の宮下が本学会誌 に発表している通り，肛門癌および低位直腸癌について は、リンパ管造影は重要であり,われわれは現在もこれを 行なっております。またこれは術後のリンパ節廓清の出 来，不出来が一目で判別されるという利点もあります．

治療は原則として腹会陰式直腸切断術が施行されてお ります。．また手術不可能例おょび術後局所再発例につい ては, cryosurgery が適し，現在これを行なって好成 績をあげております。以上肚門およびその周辺部湂につ いての特徴を直晹癌と対比して検討致しました.

\section{（4）肛門部癌について}

癌研外科

○高橋 孝, 西 満正, 山田 肃

何をもって肛門部癌あるいは肛門癌とするかという定 義については，かなりの混乱がありますが，今回は，こ の定義の問題は素通りして, 消化管の出口付近に存在す る澏腫は, どのような臨沫病理学的特徴をもつかという ことを検討してみました。

一つのはっきりとした位置基準としで菌状線を採用 し，この線から癌腫までの距離をもって癌の部位を定め ました。しかし，癌腫までの距離と言っても，癌栄の下 縁までか，西るいは中心までかが問題になりますが，今 回はこの両方について検討し，これらの結果を併記して みました。

歯状線付近の管腔内面を打打う上皮は，口側から，内 胚葉系の直腸粘膜である円柱上皮, cloacogenic と考元 られている重層立方上皮, 外肧葉系の重層扁平上皮とか ら成り立っており，また，この付近の分泌機能を営む上 皮組織としては, anal buct, aberrent gland, apocrine gland があります.

さて，1970年末までの癌研外科の直腸癌症例471例を， その中心と下縁によって分類してみました，

歯状線の口側 $1 \mathrm{~cm}$ に一つの線を引いた理由は，この 付近が，いわゆる anal canal の始まる部分であるこ
と，及び，先に述べた重層立方上皮がこの線以下で円柱 上皮に連っているという二つの理由からで，従って，部 位別の分類, 歯状線上 $6 \mathrm{~cm}$ 以上, $1 \mathrm{~cm}$ から $6 \mathrm{~cm}$ の間, $1 \mathrm{~cm}$ 以内拈よび歯状線以下としました。

癌の中心が歯状線上 $1 \mathrm{~cm}$ 以下にあるものは 20 例 $4.2 \%$ であり，癌の下縁が歯状線上 $1 \mathrm{~cm}$ 以下にあるものは 110 例 $23.4 \%$ であります，また歯状線上 $1 \mathrm{~cm}$ 以上に中心の

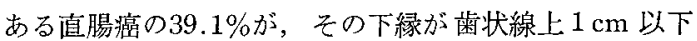
にあり，10.7\%が蒾状線を下方一越えています。

以下症例を $2 ， 3$ 供覽いたします。

60 歳の女性で, 10ケ月の肛門出血を訴え，中心は歯状

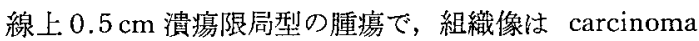
stratum spinocellulare の像を示し, 角化傾向は認めら れません。

59歳の女性で，2 2 月の肛門出血を訴え中心は歯状線 上 $0.5 \mathrm{~cm}$ ，組織像は前例之同梯の扁平上皮癌でありま 9 .

54歳の男性で， 1 年10ケ月の肛門出血索訴え，中心は 歯状線上で壁外発育型を示し中心に瘦孔があります，粘 液結節癌の組織像です。

65 歳の女性で， 5 年間肛門部の腫瘤を訴えておう，中 心は篓状線值上で，下縁は $2.5 \mathrm{~cm}$ 下方に越えています。 組織像は乳頭管状腺癌であります。

このような症例を，各臨床病理学的项目に従って検討 してみたわけですが，まず，組織型をみてみました。

粘液癌の頻度は，癌の部位が下方になるに従って高く なり，特に癌の下縁をみていくとその上昇がはっきりし ま寸，歯状線以下に中心をもつ癌 5 例のうち 3 例怗粘液 癌であり 2 例は乳頭状および管状腺癌でした．また，扁 平上皮澏 5 例のうち 4 例恃 歯状線上 $1 \mathrm{~cm}$ 以内に中心 かあり，1例は $1.5 \mathrm{~cm}$ に中心がありました。

次に大きさ，長径をみてみました。癌の中心でみてい きますと，歯状線以下に中心のある20例のうち 2 例が 6 $\mathrm{cm}$ を越えるのみですが，癌の下縁でみてみると，当然 のことながら，下縁が下方になると大きさが增していま す。

癌の環状発育程度をみてみると, ほぼ長径と同様のこ とが言えます。

癌巣の中心をみてみました，直腸の上部では，前後壁 に中心をもつものが，左右壁のそれょり1.5 2 倍多い のですが，中心でみても下縁でみても，下方になると中 心の位圆には差がなくなっています。

肉眼形態をみてみました。中間型，浸潤型を示すもの は，中心でみていきますと，ほぼ12\%前後ですが，歯状線 上から $1 \mathrm{~cm}$ 以内のものは 15 例中 5 例が，非限局型を示 しています.しかし，下縁でみて行きますとっこの部位に 
下縁をもつ癌は压倒的に限局型が多くなっております。

深達度ですが，a2，a3 すなわち獎膜あるいは外膜を明 らかに越えるものの割合は, 中心でみてみると, 癌の部 位にかかわらす $30 \%$ 前後ですが，下縁でみてみると，下 縁が蔽状線に接するものに，わずかに外膜を越える例が 多いようです。

リンパ節転移の状態をみてみますと，かなりの特徵が あります，まず中心によってみてみますと，中心の位置 によるリンパ節転移率には差がありません，50\%前後で す. しかし，側方転移は，歯状線上 $1 \mathrm{~cm}$ から $6 \mathrm{~cm}$ の 間に中心をもつ癌の $20 \%$ に市た歯状線直上から $1 \mathrm{~cm}$ 以内に中心をむつ癌も同しくく20\%に認められます. 鼠径 部転移は，歯状線以下に中心をもつものの16\%に認めて います。

下緣でみてみますと，下緣が歯状線上 $6 \mathrm{~cm}$ 以上およ び歯状線上 $1 \mathrm{~cm}$ 以内のものに，リンパ節転移率が $50 \%$ を割って抢り，特に菊状線上 $1 \mathrm{~cm}$ 以内のものは $35.5 \%$ の低転移率です．側方転移は歯状線上 $1 \mathrm{~cm}$ から $6 \mathrm{~cm}$ に 下縁のあるものの33例（全例の $17 \%$ ，転移例の30\%）に 認めました。

鼠径部転移は，歯状線以下に下縁をもつ癌の9例（全 例の $21 \%$ ，転移例の $38 \%$ ）に認めて㧍り，これ以外では， 歯状線上 $0.5 \mathrm{~cm}$ に下縁をもち, 三力向転移を示した 1 例に認めるのみでした.

以上の検討を中心に，下縁にしたがって各部位別の特 徵ををとめてみますと，

中心が歯状線から $1 \mathrm{~cm}$ 以内にあるものの特徽は, 扁 平上皮癌の多発，側方転移，鼠径部転移の頻発，歯状線 以下に中心のあるむのは，粘液癌の多発，側方転移，鼠 径部転移であります。

下縁からみてみると，歯状線上から $1 \mathrm{~cm}$ の間に下縁 をもつ癌の深達度が深いことと，側方転移，歯状線以下 に下縁をもつものの, 粘液癌, 側方転移, 鼠径部転移を 上げることが出来る.

以上のように，歯状線上 $1 \mathrm{~cm}$ および歯状線 と癌の中 心または下縁との距離によって臨床病理学的事項, とり わけ組織型，リンパ節転移に特徴があることが判明した.

\section{（5）肛門部悪性腫瘍の臨床 - 病理}

国立がんセンター

○北條慶一，小山靖夫，伊藤一三

肛門および肛門癌の定義は，まだ統一されていないの で，肚門管および肚門周辺に発生または発育したもの を肛門部悪性腫眗とすると，私ども注，過去 10 年閒に squamous cell ca. 7 例, malignant melenoma 4 例,
Paget 病 1 例, adenocarcinoma 15例の計27例を経験し た. squamous cell ca. は, dentate line より主として oral に発育したもの 4 例，外側に発育したもの 2 例， dentate line 上にあるもの1例である。

transitional cell ca. とみなしうるもの3例, anal gland duct より発生したと思われるものが1例含まれ る.なお，Morson や entity を唱えた Klotzらもい。 ているように, transitional cell ca. は臨床的には, squamous cell ca. との区別の意義は少ないので，今回 は通常の squamous cell ca. 4 例と同列に取り扱った。

次に malignant melanoma 4 例であるが,その origin が，いわゆる pecten とされているも，4例とも主とし て上方へ， dentate line 越えて大きく発育しており， その予後注他の部位の malignant melanoma と同様に 全身転移を起こしやすく予後不良である４４例中 2 例が amelonotic で, anaplastic ca. との鑑別が比較的むつ かしい.

つづいて, Paget 病1 例老経験している.一般に予後 が良好とされ，私どもの経験例も，12年前頃より肛門周 辺部に発生し次第に搪がってきたが，最近，ベータート ロン $3,000 \mathrm{rad}$ 照射で軽快せしめている。

dentate line を中心に，または，その下方が拡がった 腺癌は15例である. 大部分の origin は anal canal 上方で，下方に発育したものと思われるが，1例は dentate line より下方で，主として肚門外に発育したも のがある. 予後も不良で局所再発が多く、また予後不良 といわれる粘液産生癌が15例中，8例にみられる．

，肛門部悪性腫瘍は組織像を問わず，一般に局所再発が 多く，予後不良である. 局所再発が死亡例20例中14例に みられるのは，根治的手術といえども周辺組織に進行し て, 完全切除が不可能であったことを示すものといえよ 5 .

治療の遅延をみるに, 過半の症例 $(19 / 26)$ は, 医師によ ってかなりの期閒, 痔疾患として治療されていたり， た患者自身が痔と考えているうちに, やがて, 肛門外に 発育したものが，肚門内に還納できず，大きく発育して 始めて医師を訪孔るなどの事情がみられる。

次に, inguinal gland ヘのリンパ節転移にふれてみ たい，従来より anal tumor は, そけい部リンパ節転移 が多いとされているが，そのルートは複数と考えられ る. 私どもる肛門部に造影剂を注入し，そのリンパの流 れを再検討しているが，腸管壁内にかなりのリンパ管が 多く, しかも，直接，そけい部一行く会陰部の皮下のル 一ト注比較的弱く，肚門周辺の皮膚に発育した癌ならと もかくとして通常の肛門癌では直腸に向って上向性の発 育が多いので，進行してそけい部リンパ節転移がみられ 
る場合，皮雐癌としての会陰部皮下のルートよりもむむ しろ ishiopubicのリンパ節群, あるいは開鎖孔リンパ節 群, あるいは内腸骨リンパ節群を介してそけい部リンパ 節のルートによるものが大と考えられる.

私どもりンパ節転移陽性例をみても，そけい部のみに 転移を示したものが少なく，pelvic または，hemorrho・ idal に転移したものの中にそけい部りンパ節䎐移功みら れることなどは，この考えを support するとも理解で きる.

したがって，そけい部リンパ節転移は，その深達部に リンパ節転移のあることを示唆している可能性が大であ り,このことは, prophylactic groin dissection は余り 大きな意味がなく,また転移が確認されて, groin dissectionをやらざるを得ない場合は，浅，深リンバ節群 のみならず, extra, or intrailiac artery，閉鎖孔周辺を 含めて廓清しなければならないといえよう。

\section{（6）肛門およびその周辺に発生した癌}

\author{
大阪大学第 2 外科 \\ ○村井紳浩, 安富正幸, 進藤勝久 \\ 麻生礼三，吉川宣輝，原 満
}

従来，肛門澏哇直腸癌を含めて論ぜられることが多か ったが，その理由は肚門湢がまれにしか経験しないとい うことのほかに，肚門の概念が一定していないというこ とが大きな原因をなしているようである，肚門は発生学 的にも解剖，組織学的にも淔晹とは全く別のものであっ て，当然そこに発生した癌は直腸とは異なった観点から 考えられなければならない，胿門癌の子後は一般に悪い とされているが，その理由は肛門癌そのものに対する理 解の乏しさにも原因があると思われる。

肛門癌について検討するにあたって最初に問題上なる のは肛門管の定義である，anorectal の領域に癌があっ て原発部位がはっきりしない場合，一般に腺癌ならば 直腸癌，扁平上皮癌なら沙肛門癌 と分類されたりした が，今回はわれわれは肚阴管に発生した癌のみならず， 肛阴周聿の皮虐や女性の陰唇部の癌扩よび dentate line 以下にむで浸潤が执よんでいる下部直腸癌をも含めて肛 門とその周辺部に発生した癌と侾えた。

昭和 28 年から昭和 47 年 6 月までの約 20 年閒に肛閒とそ の周辺部に発生した癌は24例を経験した，この同じ時期 内における直腸肛門癌は 313 例あり，肛門癌の直腸癌に 対する割合恃 7.6\%であった。一般に外国で報告されて いる頻度注 3〜 5\%であるが，われわれの症例が $7.6 \%$ となかり高、值を示したのは，肛門外の皮膚や陰唇に発 生した癌も含めて検討したためである。すなわち肛門管
に発生した癌は12例で全体の半数を占め,ついで dentate line 付近に中心をもつものが 7 例で，䐈腸膨大部にあっ て dentate line にまでおよぶものが1例であった、年 跲は34 79歳で，半数以上が60歳台以上にみられ，また 男女比は 9：15で女性に多くみられた。病絁期閒を検討 してみると，比較的長いものが多く，2年以上の病絁期 間をもつものが12例で半数に拉よんた゚，この中には20年 をこえる症例が 1 例みられた。 また注目すべきこと注痔 瘦または将核の合併ないしはその既往歷をもつ症例が非 常に多いことであり24例中14例（59\%）にいずれかの疾 患を合併していた，とくに痔瘦の既往歷をもつ症例が多 く，とくに 2 年以上の病恼期閒を有する患者の半数に痔 瘦があり，そのほとんぞの患者が肛門癌と䛦断される以

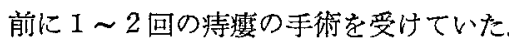

手術術式は24例中20例に腹会陰合併直腸切断術寺行な い，その中で 11 例に 兩側鼠径部リンパ節廓清術を行な い，子宮・腟合併切除術が 3 例であった，肚門外に発生 した癌に腄瘍のみの切除を行なったものが 1 例あり，人 工肛門造設術のみに終った症例が 2 例であった。

最近，われわれは陰唇部に発生した癌に対しては，外

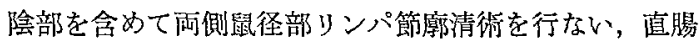
切断術を行なら手術術式を行なっている。この手術の際 には腹部の皮䖉切開は下腹部に弧状切開を加える新しい 試みをしている.この皮虐切開法では両側鼠径部のリン ハ節の廓清が容易となりすぐれた方法であると思われ る、会陰部の創は一般の值腸は癌の手術の場合々同様に 一次的に閉鎖し，仙骨前面に太、シリコンチューブを淿 入レている.

5 年生存率を検討してみると，昭和 28 年 42年むでの 15年間の肛門およびその周辺部の癌は14例で，その中， 根治手術例は 9 例で全例に follow up がなされ，その 中6 例 $(66.9 \%)$ が 5 年以上生存している，同心期間内 における直腸潋の 5 年生存率は $50 \%$ であるのに反して, 肛門癌は $66.9 \%$ とかなり良好な成續であった。この6 例 の患者はすべて 10 年以上生存しており，これらについて 検討した，腫晹の大きさは肚門全周にわたる比較的大き なものが 2 例， dentate line に中心をもつものが 3 例， 肚門外の小さな腫褂が 1 例であった。この小さな症例に 対しては腫瘍のみの切除に終っているのにもかかわらず 良好な予後をとっている，その他の症例に対して恃すべ て Miles の術式により直腸切断術が行なわれている. 組織像は扇平上皮癌が 3 例で半数を占め，めずらしい基 底細胞癌が 1 例みられた。鼠径部りンパ節の転移はほと んどの症例にみられなかった。

最近，われわれが経験した肛門外に発生した大きな癌 を示す。約 3 年前上り肍門外に腫㾇形成があり， 1 年前 
より急に増大したもので, 両側鼠径部のリンパ節の腫脹 は認められなかった，下腹部弧状切開にて開腹し, Miles 術式により直腸肚門切断術を行ない，両側鼠径部リンパ 節の廓清を行なった．腫瘍の大きさは $15.5 \mathrm{~cm} \times 8.5 \mathrm{~cm}$ の巨大なむので，瘦孔が譛められ，組織像では粘液結節 型腺管腺癌であった．このような症例は瘦孔より癌が発 生したと想像できるが，癌が㾇孔をもたらしたのではな いかという疑問が当然出てくる，瘦孔と癌がどららが先 行したかを決定するのは非常に困難である。このような 大きな肛門䲣に対しては，われわれは肚問部のみならず 臂部の健常な皮膚を含めて，できるだけ広く腫場を切除 して, 会陰部の創は開放したままガーゼで圧迫する方法 をとっている.

\section{発言}

(司会) 吉 雄 輀 文

討論のテーマとして, (1)病理, (2)良性肛門疾患との合 併, (3)進展（直接, 経静脈, リンパ行性) とくに值腸癌 などとの比較について，(4)手術法やそれ以外の治療法， を選びました。

まず病理について荒川健二郎先生む願いします。

\section{（7）肛 門 癌}

\section{荒川外科医院 荒川健二郎}

数年前肛門部に溃瘍形成を伴った手拳大の缰崲を有す る患者を某大病院にお願いしたところ, 病理組織学的腺 澏であったので直腸癌の肛門方向への浸潤と考えられ るとのご返事を得たことが岕る。しかしこの症例は臨床 的に明らかに主腫瘍塊は肛門部にあって，直腸へはむし ろその漫潤と考えられたので, たとえ腺癌でも肛門癌と いうべきではなかろうかという疑問を持ったのが，私が この問題に與味をいだくょうになった始まりであった。

現在私は肉眼的に主として肛門部を占める癌はその組 織像のいかんを問わず肛門癌あるいは肛門部の癌と言う べきであると考える．欧米の文献では肛門癌はすべて扁 平上皮癌であるごとく記されているものが多いが，皮膚 癌の発生率が著明に異なる彼我の人種的㐙異を考えただ けでも, 安易に欧米の文献を引用してこの問題を片づけ るべきではない，もし肛門部の癌を診たら，原発性か否 か, 原発性とすれば病理解剖学的に主腫瘍塊の占める部 位はどこか, その組織像は何か, そしてもし可能ならば 推定される発生母組織は何か等を各症例につき正確に記 録し，症例を重祇た上で改好て肛門癌とは何かが問われ なければならないと考える。

只今発表された各演者もこのような方針を採られ，肚 門部に発生した癌には扁平上皮癌のみならず各種の組織 像のものが存在することを示されて，私の考えが謂りで なかったことを教えていただいた。
座長より私に与えられた主題は, “肚門部の癌の発生 母組織”ということであるが，もとより正確に判定する ことは出来ない，そこで逆に肛門管に見られる正常の上 皮性成分につきスライドで示し，その各部上り発生が想 定される癌の組織像につき述べたい．

肛門の周囲の皮膚は, 毛根・皮脂腺等皮膚附属器の存 在によって, 肛門管上皮と組織学的に判別出来る. 肛門 管の下半部すなわち入口部より歯状線ないしは肛門腺窝 (肚門小㸗)縁に至る間は, 軽度ながら角化をも示す重層 扁平上皮で, 細胞間橋も明らかに諗方机る。この部分 より発生する癌惼平上皮癌であろうと推定される。肛 門管の上半分には 2 種類の上皮に覆われた部分がある。

すなわち内括約筋上縁では直腸粘膜上皮に連続する単層 円柱上皮が見られ分泌像も明瞭で腸腺も認められる。こ の部分より発生する癌は腺癌であろうと考えられる。歯 状線ないし肛問腺窩縁より上方 $1 \sim 1.5 \mathrm{~cm}$ の範囲はい わ沛肚門の移行上皮といわれる上皮組織上りなり，数 層よりなる多列附上皮ないし多列立方上皮で角化は見 られずまた細胞間橋も無く，表層の細胞には時に分泌顆 粒状の空胞が認められる。この部分の上皮は発生学的に 胎生期の総排泄孔（cloaca）に由来するといわれる。こ のいわゆる移行上皮は漸次肚門腺導管上皮上り肚門腺腺 房上皮一と移行するにつれて次筑に単層化し分泌空胞を 有する単層立方上皮となる。このいおゆる移行上皮の部 およびそれに連続する肚門腺組織の上皮上り発生する癌 の組織像を推定することは困難であるが，扁平上皮癌の 方向にも腺癌の方向にも分化し得るものと考えられる。

質問 (司会) 吉 雄 敏 文

発生母地の問題でしたが，これについての討諭はあと にしてまず rare case を伺ってみたいと思います。

答 (東大) 原宏介

細網肉腫の一症例を持っております. 非常に rushに 経過し，受診時すでに，臂部全体を占め，どこから出た のかわからない状態で，ほかの肛門部の癌との違い，潰 瘍形成，あるい怙粘液産生が芫られません，鼠径リンパ 節には明らかな転移がありました。

質問 (司会) 吉雄敏文

次にや法り珍しい extramammary Paget の症例高 橋先生，北條先生が抒持ちのようですが.

答 （癌研）高橋孝

肚門部の Paget 病変 3 例を経験しております。 50歳 代が 2 人，60歳代 1 人で，いずれも男性です，3人とも 画状線直上に接寸るか，あるいはやや上方の乳頭管状腺 癌を伴って扔ります，2例において連続切片で Paget 病変との連続を認めており，この意味では “Pagetoid disease”とも云うべきではないかと思います，但し肉 
眼的には上ほど注意しないと見過してしまうほどの病変 でした.

$$
\text { 答（がんセンター）北 条 磨一 }
$$

陰部に存在する 3 例の Paget 病のうち明らかに analmargin 原発と考えられるものが 1 例あります。74歳の 男性ですが，14年前に Pruritus ani がありそのときか ら肛門のまわりが㤸ったというのですが，14年の間に どんどん大きくなり調べた結果 Paget 病でベータ・ト ロンを 3 年吕りかけました。

それから半年くらいたって，隆起はなくなって pig一 mentation だけが残り現在 4 年経過しておりますが，再 発注認めて拈りませ九。そ他にも extramammary Paget 病は，10例ばかりあり，上皮内癌で予後はいいこ とになっておりますが，2例ばかり全身転移をしたもの が离りまして，必ずしも予後すべて良好というわけには いかないように思って㧍ります。

\section{質問 （司会）吉 雄 敏 文}

ありがとうございました，次に高野先生，malignant melanoma と neurilemmoma の症例について.

答 （社保中央病院）高 野 正 博

肛門 直腸周辺に発生した neurilemmoma 洁非常に 局所再発性が強く，何度手術してもまた再発してきま す。症例の女性も局所切除を 3 回絽り返しましたが，組 織像で再発を繰り返すうちに規則的な細胞の配列が崩れ てきて細胞の大小不同，核の mitosis，血管の増大など の傾向が強くなった症例です。

次の症例㤝73歳, 女性で, $7 \sim 8$ 年前加ら肚囲におで きができて痒いという，何か前癌状態があったので活な いかと思わせる症例です、見ますと,肛国に黑色の病変が あり malignant melanoma の臨床的診断を下し, biopsy をとりますと，その組織像注限局性の nester 老形成す る比較的良性の basal cell carcinoma ですが細胞外に, メラニン色素を認める症例です。
質問
(司会) 吉 雄 敏 文

このよらな組織像に対して病理学者は basal cell epithelioma という言葉のほうをむしろ便うようですけ れども，臨床的には如何でしょうか。

\section{答阪大) 村 井 紳 浩}

以前，そういった例を経験しましたが，組織学的にも 招となしいタイプで，12 13年生存して抢ります。

\section{質問 \\ (司会) 吉 雄 敏 文}

このほか Bowen’s disease などの稀れな疾患を除外 しますと，肚門部に発生する癌は，外側加ら epidermoid cancer, 次に cloacogenic lesion といわれる形, それ よりちょっと上方の anal duct から発生する adenocarcinoma,が一応 anal cancer の範疇に入るのではない
かと考えます。ここで anal duct から出たと組織学的 にはっきり云える症例を紹介していただきましょう。

答 (癌研) 高 橋 孝

組織学的な証明ではないんですが粘液澏の15例の内に 壁外発育を示すものが 5 例あり，その内の 4 例に痔瘦方 合併して抢ります，その割面像を見すすと屚平上皮と円 柱上皮との移行部の筋層に muconodular に浸潤して扔 ります。このょうなものを anal duct よりのものと定 義うけるとすれば 4 例ということになります。

\section{答 \\ （社保中央病院）高 野 正 博}

同じく colloid carcinoma の症例ですが anal duct が屚平上皮と円柱上皮との移行部にあってその奥が cystic にふくらんで colloid carcinoma に連絸していま す. 打そらく anal duct から発生したものと思います けれども，高橋先生もおっしゃったように，壁在性のも のが anal duct 几破れて出てきたという可能性もある わけです。

質問 （国立がんセンター）北条慶 一 いまの症例ではいずれも muconodular type を analgland carcinoma としで扔りまず，そうだからとい って特に決められた理由は，ちょっと芝しいのじゃない かと思いますが….

$$
\text { 答癌研) 高橋孝 }
$$

ご指摘の通りで組織像からははっきりしたきめ手はな いと理解して抢りますが，粘液涭であって壁外に発育し ているという意味で肛門腺よりの発生が考えられる4例 といらことにして申しあげたわけです。

質問 (间会) 吉 雄 敏 文

いろいろご意見もあるかと思いますが，先へ進みま す.

次は直腸癌に対寸る頻度ですが，村井先生は $7.6 \%$ ， これにはいるいるな形のものを含めたからやや高くそ れよりは低い頻度であううと思う九ですが，いいです 数.

次は良性肛門疾患との合併についてです，やはり痔瘦 との合併をどなたもかなり強調されていましたが，痔嗉 の悪性化にっいて打話し下さい.

答 (東大) 原宏介

癌が先行したのか将歯が先行したのかといら論議にな るとちよっとむずかしい閤題がありますが，われわれは 癌の発生に先立って痔瘦が 10年間以上存在していたとい うことを1つの判定規準にして扔ります。この上うな場 合，粘液癌が多いと報告されているようですけれども， 私たちのところはみんな管状腺癌でした。

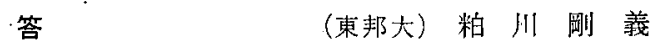
侍瘦を伴った症例はかなり多く，今まで11例を経験し 
ております，そして痔瘦あるいは肚囲膿瘍の発現後，3 年とか 1 年というょうに，かなり短かい期間に癌が見つ かることが多い上うです，その場合は侍癄から癌が発生 したのではなくて，癌が痔瘦様に発症したのではない か. 痔瘦から癌が出たと判断するには，今もお話があっ た通り非常に長い期間痔瘦が存在し，炎症が繰り返えさ れて発生してきたということの証明が一番大事でしょ 5 .

\section{発言}

（司会）吉 雄 敏 文

spread の様式については高橋先生が dentate line と の関係，北条先生が鼠径リンパ節への spread の仕方に すでに触れられましたので，次に進み，治療の問題へ移 ります，手術法としては皆さん APR にかなり広範囲な リンパ節遊清を加るのを基本にされていると思います。 まず近藤先生にご発言をお願いいたします。

\section{（8）肛門癌に対する Miles 手術の会陰創の一 次閉鎖について}

\section{大阪医科大学第 1 外科 \\ ○近藤利之，富士原彰，児玉和典 宮崎達久，安井宏明}

教室では, 従来直腸下部, 肛門癌の手術法としてMiles 術式による腹会陰式直腸切断衔をおこなってきました が，会陰創は二次癒合を営むに法数カ月を要することが 多いのであります，最近会陰創の一次閉鎖を試みわずか 2 週間で創が治愈するという好結果を得ましたので報告 します。

52歳，女子，腫瘤は歯状線部に発生した大きさ $6 \times 3$ $\mathrm{cm}$, 堤防状隆起を有するドーナツ型の肛門癌で, 組織学 的には円柱上皮細胞よりなる腺癌でありました。

手術は開腹し腹腔側で型のごとく人工肛門造設に十分 な長さで $\mathrm{S}$ 字状結腸切断，リンパ節廓清をおこない可及 的に肚門側に向って剝離をすすめます。次に側卧位と し，肛門側の操作にうつります。会陰部の皮虔切開泣肛 門輪より約 $2 \mathrm{~cm}$ はなれて 咊状に行ない背側に延長し尾 骨は全部切除します。直腸肛門を含め，病栄を完全に除 去します．ここで重要なことは止血を確実，完全に行な うことで，そのためには截石位よりも側卧位の方が有利 であります。

次に左右の肛門挙筋全層に糸を 4 5本かけて筋層縫 合を行ない会陰部の空隙をほとんぜうめてしまいます。 次に皮膚縫合を行ない会陰側は完全に一次縫合によって 閉鎖します。

次に再び仰臥位にして腹腔側から後腹膜を縫合しま す．腹膜縫合と筋層縫合との間に死腔が出来ないよう出 来れば後腹膜と筋層とを縫着させることが理想ですが，

出来ない場合はこの死腔に腹膜側からドレーンを 1 本挿 入し，腹腔を閉鎖し人工肛門を作成して手術を終りま す。

術後 2 週間で会陰側は治瘾し, 従来の二次的治瘾を営 ましめる方法にくらべてはるかに治癒日数が短縮された のであります。

肛門括約筋の機能が完全に消失するような手術では腹 部に人工肛門を造設しなければなりませんが，この場合 直腸癌でも肛門癌でも会陰側浪極力一次的治疻を営まし めるよう努力すべきであると考えます、

\section{㗨問 \\ （司会）吉 雄 敏 文}

ありがとらございました．会陰部の切除の量にも左右 されますが，なるべく primary に閉じようという努力 はすべきだと思います。

最後にそけい部の dissection を全例にやるべきかど うかについて，順番にお答え願えませんか。

答

私たちのところでは全例に初めからリンパ節を触れて いましたから，全例に行ないました。

答 （社保中央病院）高 野 正 博

あまりやってはおりままんが，すでに inguinal まで 来てお机ばさらに進展している可能性も多く，努力に価 いしないケースもあるのではないかと思います。

答

（東邦大）粕 川 㴊 義

われわれ肚門癌と低位の直腸癌では全例，primary に後腹膜外加行なっています。

答

（癌研）高 橋 孝

腫㷚の下縁が歯状線を越えた場合には行なうべきだと 考えて㧍ります。

答 （国立がルセンター）北 条 慶一 prophylactic に行なうことについてはかなり疑問があ ると思います。すなわちいるんなルートを介して来てい る可能性がある．その点私どもも非常に悩まされるので すが，inguinal だけを的清しても，あまり意味がない。 もし廓清するのならば，阪大のご 発表のように ileoinguinal に大きく皮膚切開を加えて廊清するか，ある いは別の治療法を考えたほうがいいのではないかと考え ております。

\section{答 \\ （阪大）村 井 紳 浩}

私のところでは主病変の大きさと場所によって廓清の 度合いを変えております. dentale line 近くの非常に小 さな癌に対しては，鼠径部のリンパ腺を予防的に廓清す ることは全然やっておりません。しかし，それが必要な 症例に対しては徽底的にやっております。

答

（大阪医大）近 藤 利 之

らちでも大体行なっております。 


\section{答}

（荒川外科医院）走川健二郎

私のところでは，手術はやりませんが，理論的には根 治を期待する上でやったほうがいいだろうと考えており ます。

\section{発言}

(司会) 吉 雄 敏 文

どうもありがとうございました，最後に鬼柬先生にご 発言をお願いいたします。

\section{発言} （松波病院）鬼束 惇 哉

肍門部の上皮性悪性腫瘍と申しますと，臨床的には割 合い少ない，肛門部観察がしやすいところであります し，簡単な診断法で割合い的確に診断が下し得るのであ りますから，臨床的にそれが少ないということは，これ は見かけだけでなしに実際に発生頻度が低いのだと思い ます。

肛門部，あるいはまた広い意味の肛門と申.しますと， 肛門の口およびその周辺から内部の肛門管の上端までを 一括した言葉と理解するのでありますが，そうしますと 先ほどからお話がございましたように，発生学的には完 全な皮膚になる部分，それからやや不完全な皮膚になる 部分，それからもら少し上のほうへいきますと，排泄口 から出た部分，あるいはさらに淔腸に関係する部分，と いうようないろんなものが集まっておりますし，それに またいろいろ付属器が附いております。こういら組織の 上皮性成分は，いずれも上皮性悪性変化を示し得るので あります、そういう意味で考えますと，こんな場所は腸 管のほかに梳ないのでありまして,言うならば,まさに上 皮性悪性腫瘍の博物館的位膡であるこう思います。？ らいう意味で私どもは, 勉強の対象とするのにいい場所 だと拷えるのであります。本日は rare case をいろいる 見せてむらい，おかげで頭の保養ができました。

肛門部の癌は少ないのでありますが，その中で，割合 い多いのが角化傾向の多い扁平上皮癌であろうと思い忘 す。そのためでしょうか，肚門癌という言葉でそ扎を代 用しよらとしておられる学者がございます。するいは肚 門という言葉を肚門の口という狭い意味で定義されて， そういうような言葉をお使いになったのかもしれませ ん. しかしこれはたとえて申しますと，腺腫だけがポリ 一プだといらようなことと同じ類いだと思うのでありま して，それを押し通すのも1つの方法かむしれませんけ れども,私どもの書いた論文を後世の学者が読んで,こと によったら惑わされるかもしれないと思いますと，けっ こうないい方だとは私は思いません．肚門癌という言葉
はやはり肚門部の癌と考えて，広い意味で使うべき言葉 じやないかと思います。言葉の話はこれでやめておきま 于.

肚門部の癌の臨床につきまして，特に只今は痔瘦を取 り上げてお話し下さいました。これが臨床の鑑別診断で 問題になって拈ります，もう1つ考えるべきことは，肛 門管の癌は痛みがあるということであろうと思います。 痛みを伴うために癌ではないと考えられる方にときどき 私はぶつかるのであります。まことに残念なことだと思 います。こういう方面に興味を持っていらっしや石先生 方が，ひとつ大いにお話しおき下さると，学問および患 者のために幸いじゃないかと思います。

次に処置の問題であります. 処置は abdominoperineal resection が本道だとは存じますが，これが㹡がってお るであろうかと思うところを，そういら予想のもとにや るという手術であります。場合によりますと取り過ぎと いらことが理論的にはあり得るわけであります。この逆 をいったのが，\&う10数年前から，たしかモーズである うと思けますが，やって拉った chemosurgeryだと思い ます．少しずつ取りながらさっそく microscopic に検べ まして，次から次へと行動範囲を抬げていくというやり 方，あれならば取り過ぎということはないはずでありま す。それに似た，と申しますと言い過ぎかもしれません が，一部似たのが，その後現われた cryosurgery ではな いかと思います、 cryosurgery む, chemosurgery の考 え方を取り入れてやっていただくと，またこの方面の治 䝤法が進歩するのじやなかろうかと期待しております。

なお，只今は外科的処置の話が主として出ました。私 どもが絶えず忘れてならぬことは，放射線の学者は肛門 部の悪性腫湯は表在性の疾患であるから私どもが治すの でありますと、こう言って扣ります。また治してくれた 症例を私ども見ております。これは絶えず頭の中に入れ て置いて，そして徹底的な手術を私どもは敢行す心゙きも のじやないかと思います。

きょうは吉雄先生が上手なご司会でみなさんの貫重な 経験を漏れなく昍き出させて下さいました．おかげで私 どもは大へん有難かったです，御礼を申しあげて私の発 言を拈和ります。

発言 (司会) 吉 雄 敏 文

討論し足りない部分を全部鬼束先生がお゙話し下さいま

した.どうもありがとうございました.

これでシンポジウムを終わりたいと思います。 


\title{
Symposium V
}

\section{Malignant Anal Lesions : Report of 8 Cases}

\author{
K. Hara, S. Tsuchiya, J. Tomiyama, Y. Horie \\ and Y. Kobayashi \\ First Department of Surgery, University of Tokyo Faculty of Medicine, Tokyo, Japan
}

\begin{abstract}
During the period of $1964-1972,8$ cases with malignancy in the anal region were admitted to our department of surgery. We have reviewed the pathology, treatment and prognosis about these cases. The conclusions are as follows: 1) They were histologically diagnosed as 6 anal carcinomas, one advanced rectal carcinoma and one lympho-reticulum cell sarcoma. 2) Out of 6 carcinomas of the anal canal and anal margin, 2 cases showed interesting histological features compatible with a diagnosis of anal duct carcinoma. The remaining cases were one squamous cell carcinoma and 3 adenocarcinomas associated with anal fistulas. 3) Often anal malignant lesions are erroneously diagnosed as benign or inflmmatory lesions, such as haemorrhoids and fistulas, prior to biopsy. Accordingly the diagnosis is apt to be done too late for the patients to receive necessary treatment. 4) The prognosis of malignancy in the anal region was poor with only 2 cases being well over two years. Both of these were included among 4 cases treated by abdominoperineal resection combined with groin dissection. On the other hand, local excision, irradiation therapy and local infusion by anticancer drugs gave poor results in other 4 cases.
\end{abstract}

\section{Anal and Perianal Cancers}

M. Takano, M. Okada, J. Hiratsuka, S. Sato, and Y. Sumikoshi,

Proctology Center Social Insurance Central Hospital, Tokyo, Japan

Fourteen cases of cancers originated from the anus and in the vicinity were analysed clinically and pathologically. Excluded were cases of adenocarcinoma spread from the rectum to the anus.

The pathology of 2 cases show mature, keratinizing epidermoid carcinoma, one of which originated from chronic fistula. Other 2 cases are epidermoid carcinoma consisting mainly of basaloid cells with slight tendency of keratinization. The other case is non-keratinizing so-called transitional cell carcinoma. Abdominoperineal resection was performed to them but their prognosis are not always favorable.

The 6 th is a case of benign basal cell carcinoma, which was mistaken for malignant melanoma because of dark pigment.

The pathology of the 7th case is mixture of adedocarcinoma and epidermoid carcinoma 
and the 8th case shows epidermoid-typed adenocarcinoma, both cases suggesting their origin from transitional zone of the anus. Abdominoperineal resection was in vain in both of them.

The 9 th case is a very rare case with epidermoid carcinoma in the upper part of the rectum, the etiology of which is still speculative. The 19th case is adenocarcinoma of anal origin spread to perianal area.

The last 4 cases are colloid or mucinous carcinoma in perianal or perirectal area. One of them is originated from anal fistula and another from anal gland. Their prognosis so far is good in comparison with other types.

In summary, the origin and pathology of anal cancers are so diversified that authorized classification is awaited for the research. Most of our cases are progressed cancers and their prognoses were not always favorable although abdominoperineal resection was performed for all of them and in this respect, keratinizing mature epidermoid carcinoma was not exmpted. The exception is colloid (mucinous) carcinoma of perianal and perirectal regions.

\title{
3. Malignant Tumors of the Anus and Anal Canal
}

\author{
K. Hojo, Y. Koyama and I. Itoh \\ Devision of Surgery, National Cancer Center Hospital, Tokyo, Japan
}

Twenty seven cases of malignant tumors of the anal region were treated in our hospital for the past 10 years, which were studied clinical and histological.

There are 7 cases of squamous cell carcioma ( 3 cases of them are possibly arisen from transitional cloacogenic zone), 4 cases of malignant melanoma, one case of Paget's disease and 15 cases of adenocarcinoma.

The prognoses are poor, except 5 cases of adenocacinoma in the relatively early stage and a case of Paget's disease. Local recurrence is very freguent. Most cases were treated initially as benign anal diseases and lost the chance of early treatements.

The routes of spread to inguinal lymph nodes are also discussed. We point out that such routes as anorectal $\rightarrow$ ishiopubic $\rightarrow$ inguinal, anorectal $\rightarrow$ obturatoric $\rightarrow$ inguinal, and anorectal $\rightarrow$ pelvic $\rightarrow$ internal iliac $\rightarrow$ inguinal are more frequent than the perineal cutaneous routes.

So the significance of prophylactic groin dissection is questionable and, when inguinal metastasis is positive and the dissection of them is demanded, we should do extensive ileoinguinal en-bloc dissection with postoperative adjuvant therapies as radiochemotherapy. 


\title{
4. On Anal Cancer
}

\author{
T. Takahashi, M. Nishi and S. Yamada \\ Cancer Institute Hospital Department of Surgery, Tokyo, Japan
}

When 471 recto-anal cancers are divided into several groups according to the distance from their centers or the lower borders to the dentate line, some distinct clinico-pathological features can be disclosed in the groups (1) within $1.0 \mathrm{~cm}$ above the dentate line and (2) below it.

All of 5 cases of squamous cell carcinoma (probably cloacogenic carcinomas), are situated within $1.5 \mathrm{~cm}$ above the dentate line, and colloid cancer accounts for $60 \%$ of all cancers below the line. Inguinal metastases are positive in 16 of 43 cases the lower border of which extend down over the dentate line.

\section{Cancer Which Developed at the Anus and its Vicinity}

\author{
N. Murai, M. Yasutomi, K. Shindo, R. Aso, \\ N. Kikkawa and M. Hara \\ The 2nd Department of Surgery Osaka University, Osaka, Japan
}

For 20 years from 1953 up to 1972, we experienced 24 cases of cancer at the anus and its vicinity out of 313 cases of rectal cancer (7.6\%). Of these 24 cases, 20 cases were treated with abdominoperineal resection (Miles). The ratio of both sexes was $9: 15$ in favor of female and their ages ranged from 34 to 79 .

The operation method is abdominoperineal resection in which a wide area the skin, subcutaneous fat and muscle are resected. Groin dissection is conducted in principle. Dissection of superior rectal artery is done at the branching point of inferior mesenteric artery from aorta and it is dissected en bloc. Recently we apply arch incision to rectal cancer as it facilitates dissection of lymph nodes along bilateral inguinal regions and external iliac arteries. Against vulva cancer, we apply rectal resection in combination with partion resection of the vagina.

Out of the 24 cases, four suffered from anal fistula which had persisted for long time. They were all muconodular adenocarcinoma localized type with little lymph node metastasis. 


\title{
6. Primary Closure of Perineal Incision after Miles' Operhtion for Anal Cancer
}

\author{
T. Kondo, A. Fujiwara, K. Kodama, T. Miyazaki \\ and $\mathrm{H}$. Yasui \\ First Department of Surgery, Osaka Medical College, Osaka, Japan
}

Fifty-two year old woman was operated for anal cancer about the size of a pigeon's egg on the dentate line. Miles' technique was used for combined abdominoperineal resection of the anorectum.

Muscular layer and the skin were sutured separately in the perineal incision in a primary suture. The retroperitoneum was closed as much as possible, a drain was inserted into cul de sac and then it was closed with sutures.

Two weeks after the operation the wound almost completely recovered.

Until now, when Miles' technique is used for anorectal cancer, the perineal wound is cured after a few weeks or months. But, when the levator ani muscle and the skin are sutured primarily as described above and when a drain is inserted from the abdominal side into the cul de sac formed between the sutured levator ani muscle and the posterior peritoneal sutureand if antibiotics and antiphlogistics are used together, healing is achieved in 2-3 weeks.

\section{Carcinoma of the Anal Region}

\author{
K. Arakawa \\ Arakawa Surgical Clinic, Tokyo, Japan
}

Confusion exsits at present regarding carcinoma of anal region, because of complicacy of lining cells in this area. Three kinds of epithelium are observed in the anal canal, that is, stratified squamous, so-called transitional and columnar epithelium.

The epithelium lining the lower part of the anal canal, between anal verge and dentate line, is the stratified squamous epithelium with keratinization and identical to perianal skin except absence of hair, sebaceous and sweat glands. Malignant epithelial tumor arise from this area should be squamous cell carcinoma. The co-called transitional epithelium is observed in a narrow zone above dentate. line and anal ducts. .. It is estimated that both squamous cell carcinoma and adenocarcinoma are able to arise from this type of epithelium. From the columnar epithelium, which covers the upper third of the anal canal, adenocarcinoma should be arise. 